\title{
THE GROWTH STAGES AND ADULT STRUC- TURE OF THE LOPHOPHORE OF THE BRACHIOPODS MEGERLIA TRUNCATA (L.) AND M. ECHINATA (FISCHER \& OEHLERT)
}

\author{
By D. Atkins, D.Sc. \\ From the Plymouth Laboratory
}

(Text-figs. I-I6)

Two species of Megerlia, truncata and echinata, have been dredged by R.V. 'Sarsia' in recent years, allowing of a study of the growth stages of their lophophores and of the feeding mechanism. The generic position of M. echinata has already been discussed (Atkins, I96I $a$ ).

\section{MEGERLIA TRUNCATA (L.)}

Megerlia truncata was dredged in February and July 1956, and again in June 1957, from a small area of yellow coral, Dendrophyllia cornigera Lamarck, off the Point of Penmarch at a depth of $45-48$ fathoms. They were attached to the dead region of the growing coral, in company with Terebratulina retusa (L.) and Platidia davidsoni (Eudes Deslongchamps). They varied in size from a shell length of $I .5 \mathrm{~mm}$ and width of $\mathrm{I} \cdot 2 \mathrm{~mm}$ to a shell length of $\mathrm{I} 6 \mathrm{~mm}$ and width of $\mathrm{I} 8 \mathrm{~mm}$. Fischer \& Oehlert (189I) gave the length as $9 \mathrm{~mm}$ and width II mm, whereas Davidson (I887) gave the length as 9 lines and width Io lines, which is about $19 \mathrm{~mm}$ by $21 \mathrm{~mm}$. The shell of the young is longer than wide, but this relationship changes with increased size.

The pedicle opening is large and submesothyrid (Thomson, 1927). However, in two individuals of length 2.8 and $4.3 \mathrm{~mm}$, a shallow semicircular notch was present in the dorsal valve (Figs. 3, 5), and in one of length $6 \mathrm{~mm}$ and width $7.2 \mathrm{~mm}$ the semicircular notch was in a plane at right angles to that of the valve. The shell of length $2.8 \mathrm{~mm}$ and width $3.1 \mathrm{~mm}$ was not flattened on to the substratum, but stood almost vertically, as is usual in Megerlia truncata. The position of attachment of the other two was not especially noted.

The shell of adults is of a fulvous colour, that of the young whitish or yellowish. In the adult the flesh was of a dark orange colour: in a small specimen of length $3.9 \mathrm{~mm}$, while the flesh was an orange tint, the digestive diverticula and gut were dark brown. Mantle setae were present in both young and adults; in the latter the follicles were orange tinted. Mantle setae appear especially long in the young: they have been omitted from all figures. 
Between the mouth and the transverse band of the loop are two carmine pigment spots, such as noted in certain other brachiopods (Atkins, I959 $a, c$, I96I $b$ ). It may be recorded here that the posterior adductor muscles are striated.

Results of narcotizing $M$. truncata were variable, but on the whole young stages were difficult to relax successfully.

All figures in this and the following section on M. echinata were drawn with the aid of a camera lucida.

\section{Growth stages of the lophophore and loop}

Young stages of the brachidium of $M$. truncata at 2 and $4 \mathrm{~mm}$ shell length have been described and figured by Eudes Deslongchamps (I884) and by Fischer \& Oehlert (I89I) at $4 \mathrm{~mm}$ long, but the relationship of lophophore to loop has so far not been described in detail.
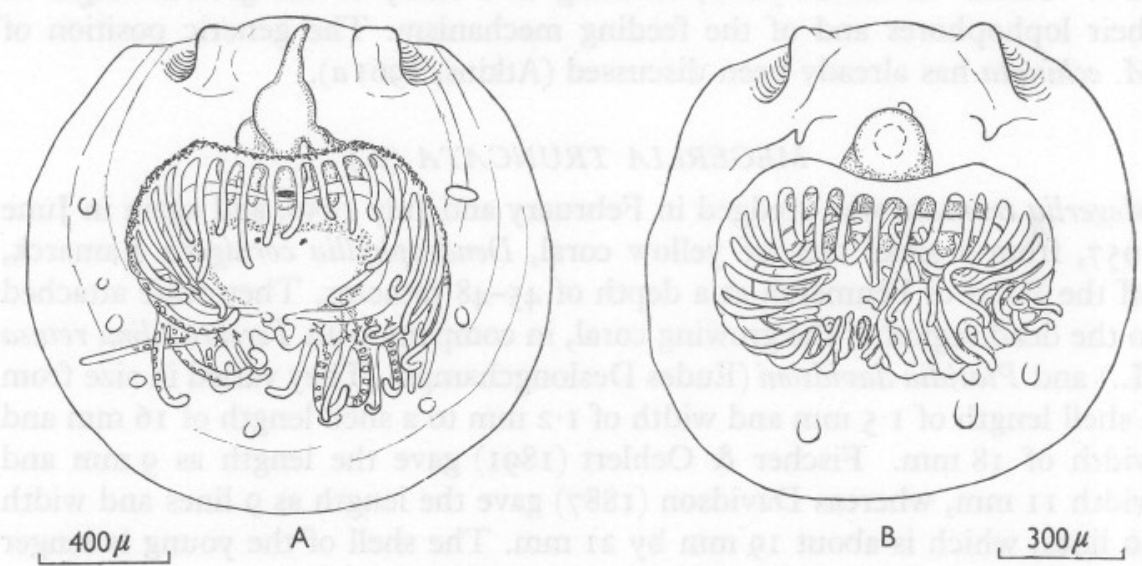

Fig. I. Megerlia truncata. A. Brachial valve of a specimen of shell length and width $\mathrm{I} \cdot 6 \mathrm{~mm}$, drawn living, the very early schizolophe not fully expanded. The filaments behind the mouth are standing almost upright and therefore appear short. Spicules are indicated and a semicircle of mucous glands to the inner side of the food groove. The two carmine pigment spots are shown. Muscles and mantle setae omitted. B. Brachial valve of a specimen of shell length $\mathrm{I} \cdot 5 \mathrm{~mm}$ and width $\mathrm{I} \cdot 2 \mathrm{~mm}$, drawn preserved after unsuccessful narcotizing. Although of smaller size than the specimen shown in A, the lophophore is somewhat more advanced. Small crura are present and a minute double septum at the anterior invagination of the lophophore. Spicules, mantle setae, muscles and carmine pigment spots omitted: intestine removed.

A number of immature $M$. truncata were found among material dredged by R.V. 'Sarsia' from off Penmarch, but they did not furnish a complete series of growth stages of the lophophore. A fairly closely gradated series of shell length I.6-4.3 mm was obtained, but the earliest stages of the growth of the ring are unknown in this species as they apparently occur in individuals about $2 \cdot 4^{-2} \cdot 8 \mathrm{~mm}$ long and these were wanting. A large hiatus exists between 
shell lengths 4.3 and $7 \mathrm{~mm}$. At the latter size the lophophore is early plectolophous.

The earliest stage of the lophophore seen was very early schizolophous in a specimen of shell length and width $\mathrm{I} \cdot 6 \mathrm{~mm}$. Most of the filaments are in a single series with ridged frontal surfaces, although a few grooved filaments are present anteriorly (Fig. IA). The filaments are rather unequal in length; this is no doubt abnormal. Spicules support the base of the lophophore and are present in the outer filaments and in a few of the more anterior inner filaments. Crura and septum are not yet developed.

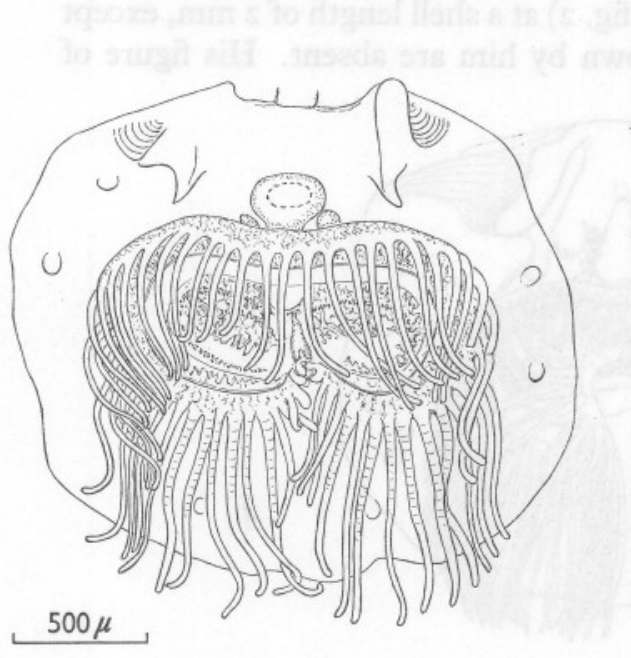

Fig. 2

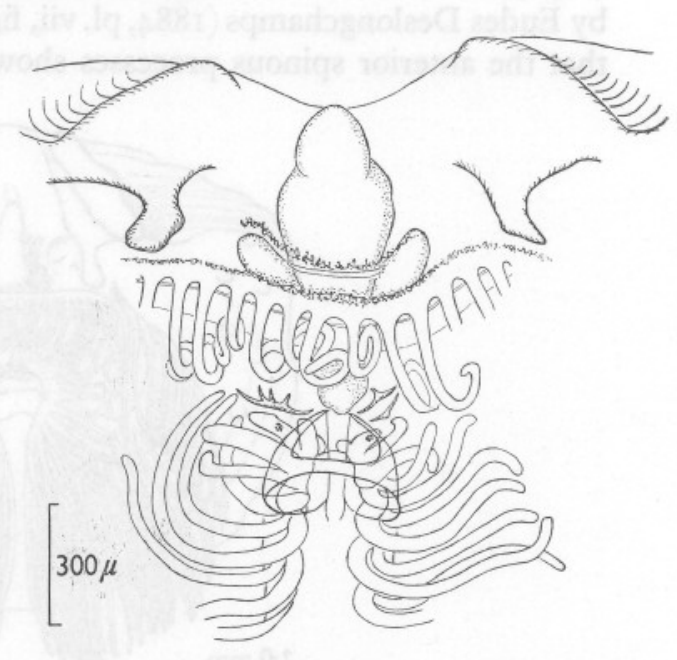

Fig. 3

Fig. 2. Megerlia truncata of shell length $2 \cdot 4 \mathrm{~mm}$ and width $2 \cdot 1 \mathrm{~mm}$. Brachial valve with early schizolophe, showing some irregularity in the arrangement of the filaments. Spiculation is indicated and the band of mucous glands on the brachial membrane. The carmine pigment spots are hidden by overlying filaments. Intestine removed. Drawn living, narcotized.

Fig. 3. Megerlia truncata of shell length $2.8 \mathrm{~mm}$ and width $3.1 \mathrm{~mm}$. Posterior region of the brachial valve to show the relation of the brachial support and the late schizolophe (somewhat contracted). The lophophore overlies most of the loop. Drawn living, the brachial support added after staining and clearing. Spicules mostly omitted.

In a slightly smaller $M$. truncata of shell length $\mathrm{I} \cdot 6 \mathrm{~mm}$ and width $\mathrm{I} \cdot 2 \mathrm{~mm}$ (Fig. IB), but with rather more advanced lophophore, minute processes arising from near the bases of the inner socket ridges represent the crura. What appears to be a minute double septum is present in the anterior invagination of the lophophore.

At a shell length of $2.4 \mathrm{~mm}$ and width of $2.1 \mathrm{~mm}$ there is an increase in the number of filaments and in the spiculation, although the lophophore is still early schizolophous (Fig. 2). This specimen shows anteriorly some irregularity in the arrangement of the two series of filaments, for on the left two 
and on the right three outer filaments occur without intervening inner filaments. An elongated hood is borne on a slight median ridge.

The late schizolophous stage has been found at the following shell sizes: (I) length $2.8 \mathrm{~mm}$ and width $3.1 \mathrm{~mm}$ (Fig. 3); (2) length $3.4 \mathrm{~mm}$ and width $3.8 \mathrm{~mm}$; and (3) length $3.5 \mathrm{~mm}$ and width $3.2 \mathrm{~mm}$. The appearance of the brachial support, so far as can be discerned by clearing the brachial valve in cedar-wood oil, is of a ring, narrow ventrally and broadly attached dorsally to a low septum; it supports the blind end of the invagination of the lophophore (Fig. 3). The state of the ring at this shell size agrees with the stage depicted by Eudes Deslongchamps (1884, pl. vii, fig. 2 ) at a shell length of $2 \mathrm{~mm}$, except that the anterior spinous processes shown by him are absent. His figure of

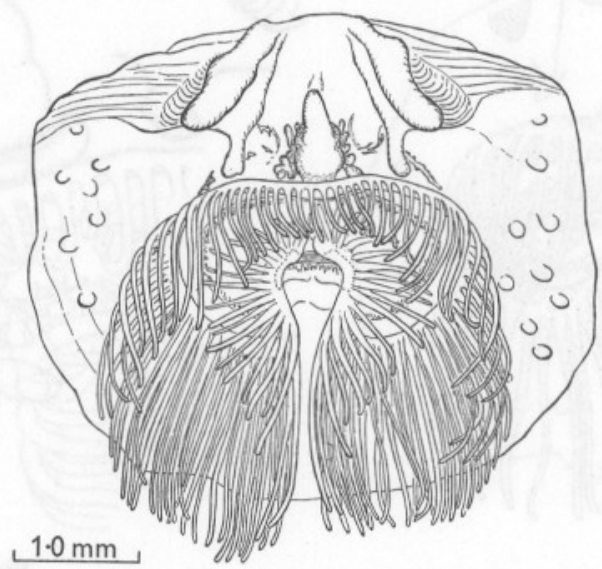

Fig. 4. Megerlia truncata of shell length $3.9 \mathrm{~mm}$ and width $4.5 \mathrm{~mm}$. Brachial valve with early zygolophe, drawn living. Position of some spicules indicated. Muscles and mantle setae omitted.

the brachial support resembles that of Terebratula lunifera (Philippi, I836, pl. vi, fig. $\mathrm{I} 6 a$ ) at a shell length of $\frac{5}{4}$ '"' and width of $\mathrm{I}^{\prime \prime \prime}$. The cardinalia of T. lunifera, however, differ from those of Megerlia truncata, though this may have been due to inaccurate drawing. It was assumed, probably rightly, by Jeffreys (1878) that Philippi's Terebratula lunifera was the young of Megerlia truncata, the adult of which Philippi also figured.

The schizolophous lophophore shown in Fig. 3 is somewhat contracted and the filaments lining the median invagination are turned outwards. When well expanded the tips of these filaments approximate, roofing in an excurrent channel; this position of the filaments occurs only previous to deflexion of the lateral arms.

The early zygolophous stage of the lophophore, with lateral arms just beginning to be deflected, occurred in three individuals. In those of shell length $3.7 \mathrm{~mm}$ and width $3.9 \mathrm{~mm}$, and shell length $3.9 \mathrm{~mm}$ and width 
$4.5 \mathrm{~mm}$ (Fig. 4) the crura are rather more developed than in the previous stage; the ring has increased in diameter, and shows laterally slight forward projections. In a somewhat larger specimen of shell length $4.3 \mathrm{~mm}$ and width $5.6 \mathrm{~mm}$ (Fig. 5) crural processes are obvious; the descending branches are short. The anterior extensions of the ring are more pronounced and have come to point outwards. As far as this stage the ring gives support to little more than the growth regions of the lophophore where spicules are few and development of supporting substance slight. The remainder of the lophophore is supported by heavy spiculation, not shown in Fig. 5. In M. truncata the descending branches of the loop are late in developing.

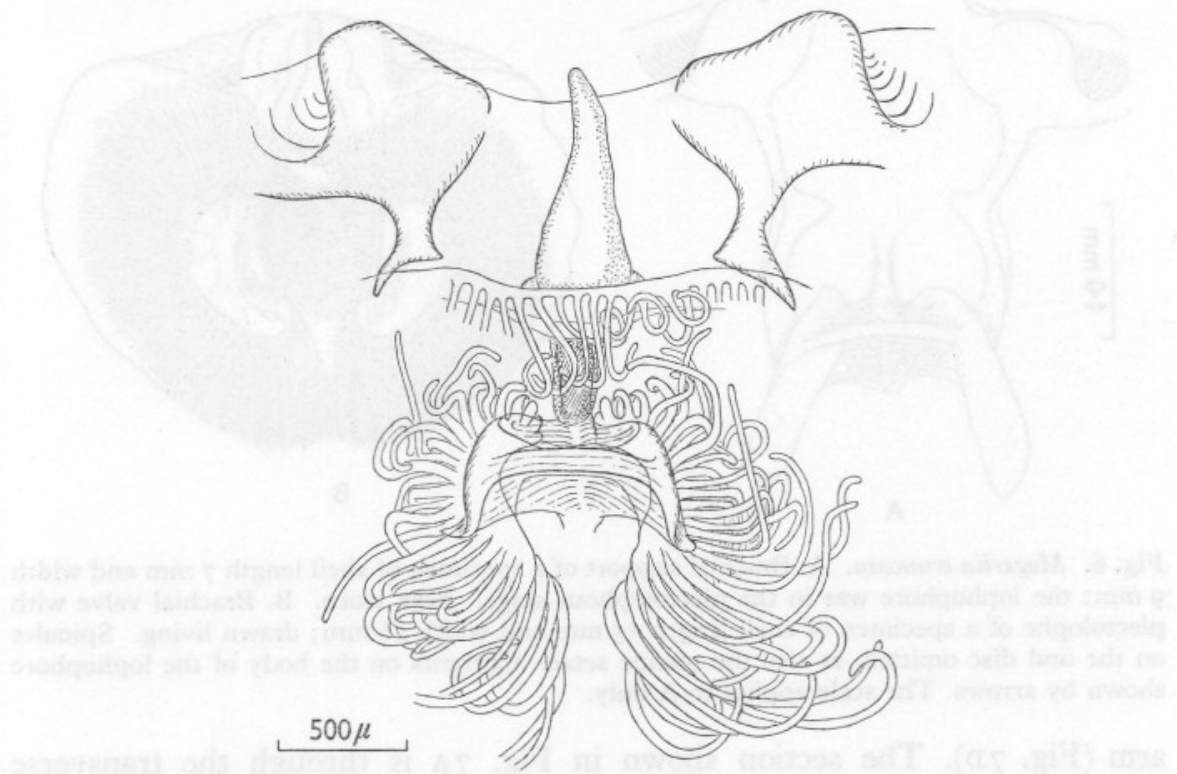

Fig. 5. Megerlia truncata of shell length $4.3 \mathrm{~mm}$ and width $5.6 \mathrm{~mm}$. Posterior region of the brachial valve to show the relation of the brachial support and the zygolophe, with lateral arms just beginning to be deflected. The lophophore overlies most of the loop. The septum is continued posteriorly under the gut, but is obscured by the thickness of the stomach. Stained and cleared. Spicules omitted.

No $M$. truncata were obtained between a length of 4.3 and $7 \mathrm{~mm}$. At a shell length of $7 \mathrm{~mm}$ and width of $9 \mathrm{~mm}$ the lophophore is early plectolophous with little more than one turn to the spiral arm. The descending branches are complete and the loop much as in the adult (Fig. 6A). At a shell length of $9 \mathrm{~mm}$ the spiral is somewhat more coiled (this individual is a male with small ripe gonad).

\section{The adult lophophore}

The adult lophophore is plectolophous. Owing to the generally short and broadly transverse shape of the shell the lateral arms are short and the spiral 
arm short and broad (Fig. 6B). The fully adult loop has been figured by several authors and may be seen in Fischer \& Oehlert (I89I, pl. vii, fig. II $g-i$ ). The relation of the lophophore to the body, and of the lateral and spiral arms to one another and to the brachial support in M. truncata of shell length $12 \mathrm{~mm}$ and width $15 \mathrm{~mm}$ is shown in transverse sections illustrated in Fig. 7 . The organic connexion between the lateral and spiral arms is extensive, as may be seen from these sections; the lateral arm and the corresponding half of the spiral arm still have a common great brachial canal when the section is anterior to the brachial membrane connecting the two sides of the spiral
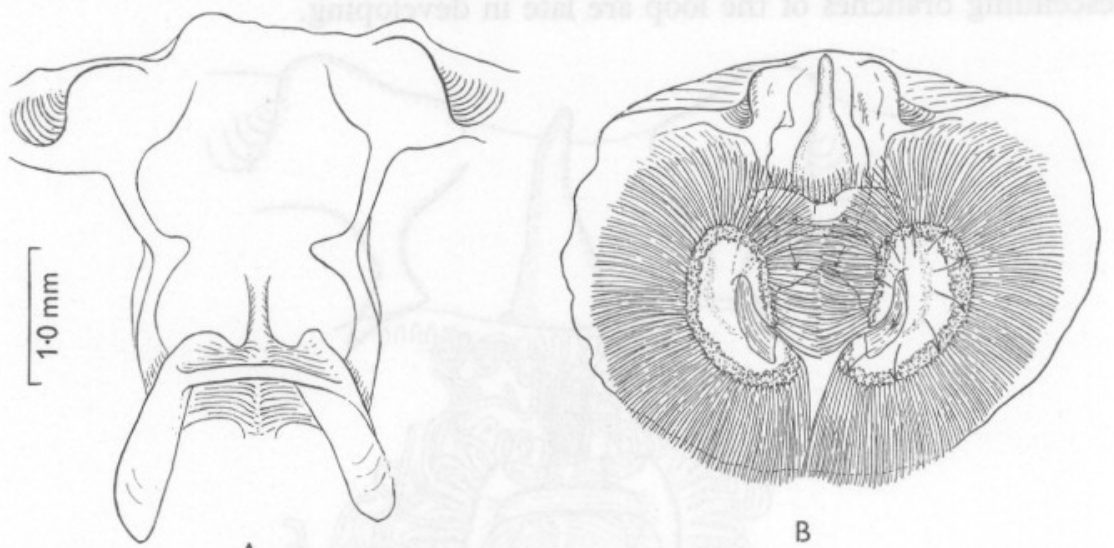

A

Fig. 6. Megerlia truncata. A. Brachial support of a specimen of shell length $7 \mathrm{~mm}$ and width $9 \mathrm{~mm}$ : the lophophore was in the plectolophous stage. Beak worn. B. Brachial valve with plectolophe of a specimen of shell length $15 \mathrm{~mm}$ and width $16 \mathrm{~mm}$; drawn living. Spicules on the oral disc omitted, as also the mantle setae. Currents on the body of the lophophore shown by arrows. The scale applies to A only.

arm (Fig. 7D). The section shown in Fig. 7A is through the transverse band and the bands connecting it with the low median septum. Below the transverse band is an extension of the mantle cavity. The coelome extends into the lateral arms, and on the left is dividing off as the brachial pouch. A more anterior section (Fig. 7B) passes anterior to the transverse band and through the descending and ascending branches of the loop. Fig. $7 \mathrm{C}$ is of a section through the twin growth regions of the lophophore at the apex of the spiral arm. The brachial membrane connecting the two sides of the spiral arm is deeply depressed medianly, so that transverse sections through the anterior region of the arm show the two sides unconnected (Fig. 7D). This incurvature of the membrane is present in life (Fig. 6B).

The broad calcareous supporting loop does not reach to the extremities of the lateral arms (Fig. 6B). A broad band of spicules is present at the bases of the filaments. Between this basal band and the edge of the loop the membrane is transparent, with only a few spicules. Indeed it is so transparent that when 


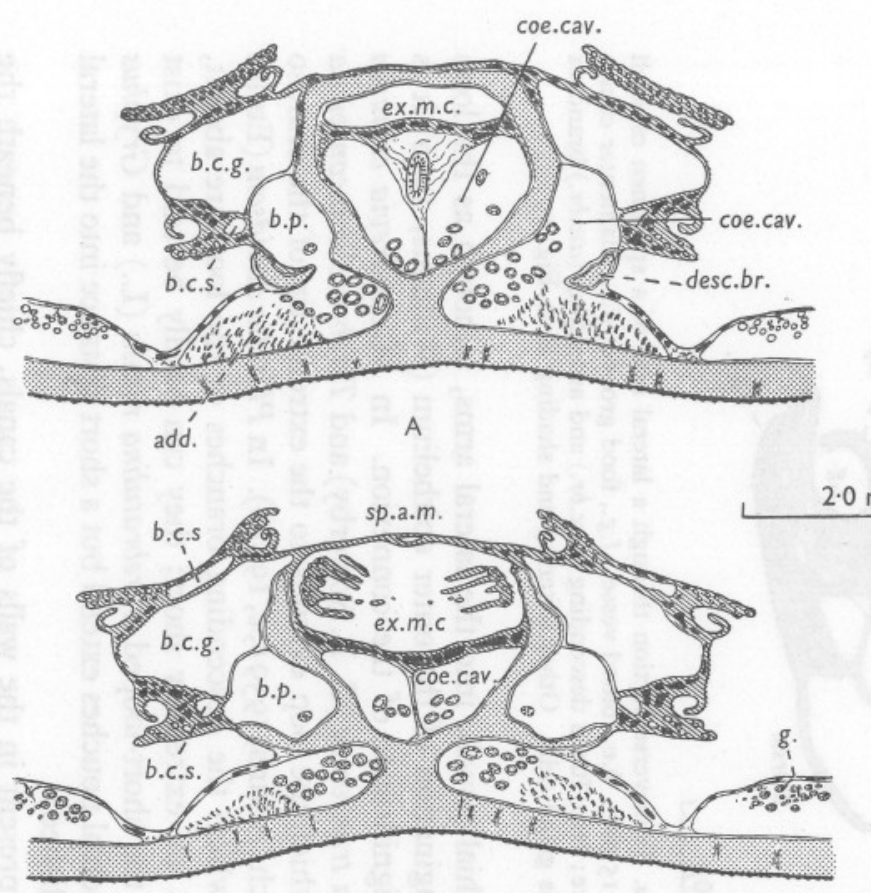

B

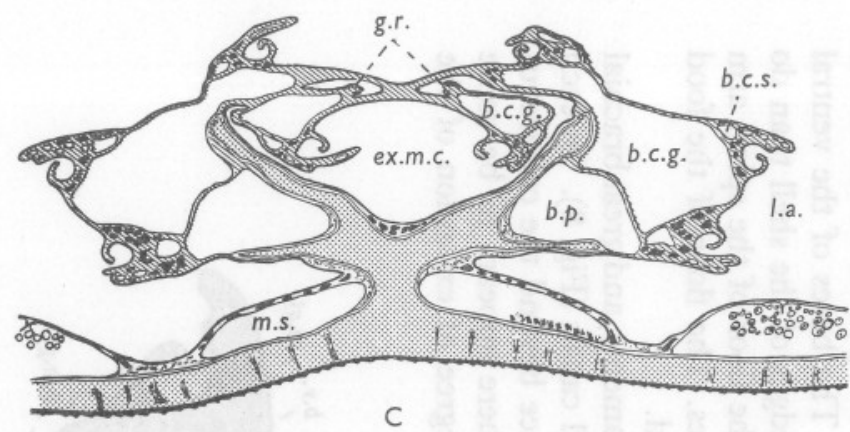

Fig. 7. Megerlia truncata of shell length $12 \mathrm{~mm}$ and width $15 \mathrm{~mm}$. Transverse sections to show the relation of the lophophore to the body. A. Through the transverse band and the bands connecting it with the low median septum. On the left the brachial pouch is becoming separated from the coelomic cavity. B. Anterior to the transverse band. The posterior end of the spiral arm is present beneath the membrane connecting the two sides of the first coil of that arm. C. Through the growth regions of the lophophore, at the apex of the spiral arm. D. Through the anterior region of the spiral arm, the two sides of which are free from one another, the section being anterior to the connecting membrane. The lateral arms are free from the septum. add., adductor muscle; b.c.g., great and b.c.s., small brachial canals; b.p., brachial pouch; coe.cav., coelomic cavity containing digestive diverticula; desc.br., descending branch of the loop; ex.m.c., extension of mantle cavity; g., gonad; g.r., growth regions; l.a., lateral arm; m.s., mantle sinus; sept., septum; sp.a.d., dorsal and sp.a.v., ventral side of spiral arm; sp.a.m., membrane connecting opposite sides of spiral arm. Spaces formerly occupied by spicules 
the lophophore is viewed ventrally the basal band of spicules of the dorsal side of the arm is visible through the membrane. The bases of the ventral filaments of the lateral arms lie nearer the lateral edges of the shell than do those of the dorsal row. The membrane forming the floor of the spiral arm is transparent and contains only a few tiny spicules. The floor of the food groove and the base of the lip are heavily spiculated.

Small brachial canals, giving off branches to the filaments, and great brachial canals are present. A blood vessel runs in the small canals (Fig. 8). In each lateral arm a brachial pouch extends a short distance beyond the calcareous loop, but not to the extreme end of the arm. There appears to be some connexion between the length of the loop and degree of extension of the

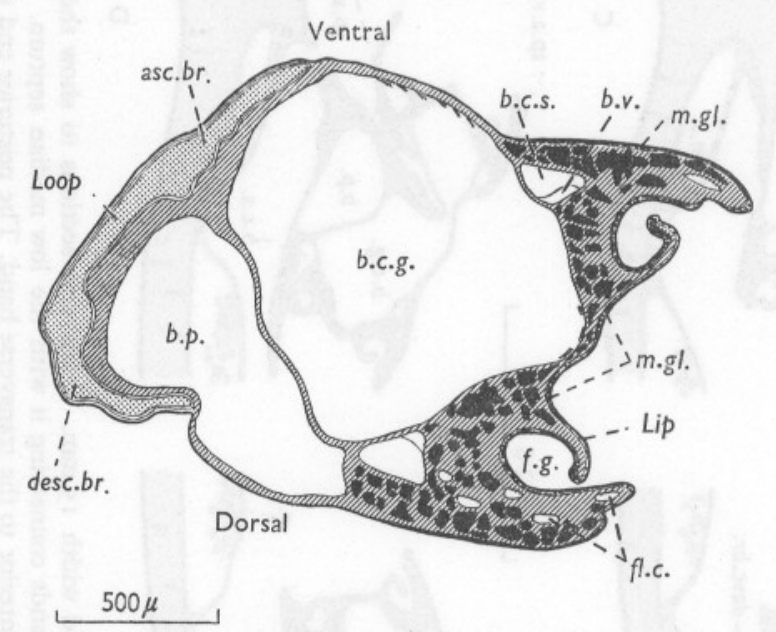

Fig. 8. Megerlia truncata. Transverse section through a lateral arm of a specimen of shell length $12 \mathrm{~mm}$ and width $15 \mathrm{~mm}$. b.v., blood vessel; f.g., food groove; fl.c., filamentar canal; Lip, lip of the food groove; loop, fused descending (desc.br.) and ascending (asc.br.) branches of the loop; m.gl., mucous gland cells. Other lettering and shading as in Fig. 7.

coelome, as the brachial pouch, into the lateral arms, although as the loop is formed by an invagination of the outer epithelium (Williams, I956) it is difficult to see the significance of the connexion. In Macandrevia cranium (Müller), Terebratalia transversa (G. B. Sowerby) and Terebratella inconspicua (G. B. Sowerby) in which the loop extends to the extreme tip of the arm, so does the brachial pouch (Atkins, 1959 b, $c$, 196 I $b$ ). In Platidia davidsoni (Eudes Deslongchamps) in which the descending branches of the loop are absent, the brachial pouches are extremely short; they can hardly be said to exist (Atkins, 1959a). In the short-looped Terebratulina retusa (L.) and Gryphus vitreus (Born) the brachial pouches extend but a short distance into the lateral arms (Atkins, unpublished).

Muscle fibres are present in the walls of the canals, chiefly beneath the 
supporting substance under the food grooves where they are mainly transverse in direction. They are too fine to be shown well at the magnification of Fig. 8 .

The filaments are in a double alternating series except for some II to I 2 pairs behind the mouth in single series and with ridged frontal surfaces. The outer filaments are rather deeply grooved, and in an adult $15 \mathrm{~mm}$ long and $16 \mathrm{~mm}$ wide were about $0.85 \mathrm{~mm}$ wide near the base, while the inner filaments were about $0.5 \mathrm{~mm}$ wide. Longitudinal muscle fibres are present in the walls of the filamentar canals, being most strongly developed frontally and to a lesser degree abfrontally. Striated fibres appear to be restricted to the frontal group.

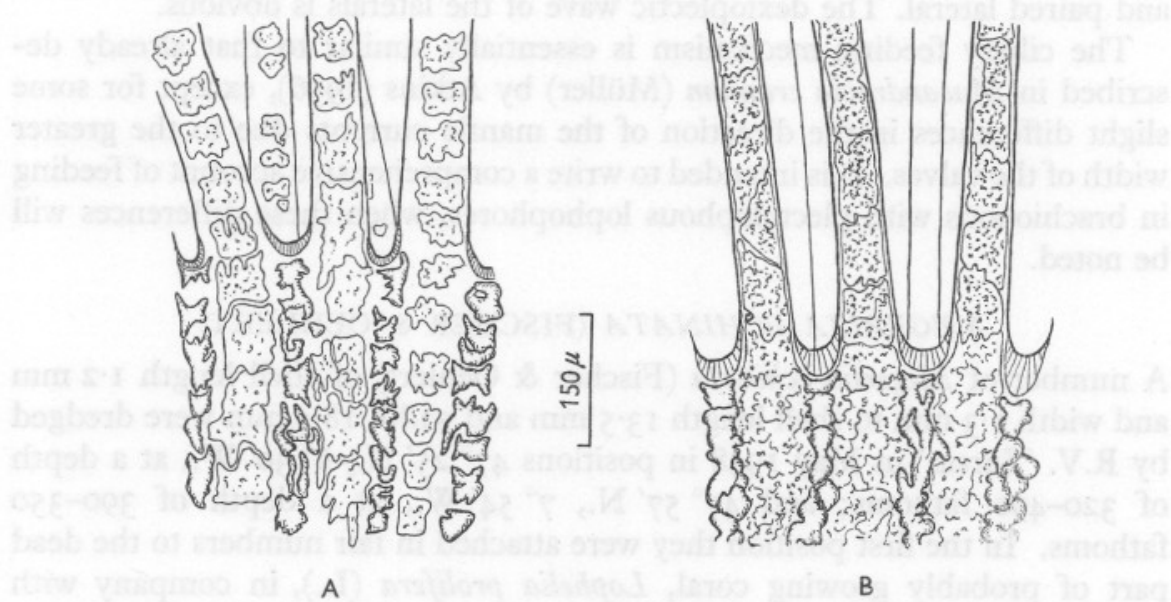

Fig. 9. Megerlia: the arrangement of the spicules in the filaments. A. M. truncata: a few filaments from the ventral side of a lateral arm of a large specimen, viewed from the abfrontal or outer surface. B. M. echinata: a few filaments from the ventral side of a lateral arm of a specimen of shell length $10 \mathrm{~mm}$ and width $12.5 \mathrm{~mm}$, viewed abfrontally.

A blood vessel runs within the filamentar canal in the usual frontal position. Embedded in the supporting substance of the filaments are spicules. These are always present in the outer filaments of the adult where they are large and granulated. The inner filaments are spiculated in some $M$. truncata and not in others, and when present the spicules are small. The spicules of the filaments somewhat resemble those present in the same position in Platidia. On the abfrontal surface of the body of the lophophore between the bases of the outer filaments, and in line with the inner filaments, are rows of spicules, which are smaller than those in the basal part of the outer filaments, but are thicker, more rounded, and clear, not granulated (Fig. 9A).

The distribution of mucous gland cells on the lophophore is similar to that in other plectolophes: a deep abfrontal band below the filaments, paired tracts on the brachial membrane, and scattered mucous cells in the walls of the food groove, including the lip. Mucous glands are especially numerous 
on the abfrontal surfaces of both inner and outer filaments, so numerous that they almost touch over the entire surface, although there is a tendency for them to be arranged in two tracts, leaving the mid line clear. Notwithstanding the presence of so many mucous cells, which incidentally obscure the spicules, a good abfrontal current to the tips of the filaments is present. It is possible that the glands have small apertures, for cilia, about $20 \mu$ long, are present over the entire abfrontal surface, although perhaps more closely set on the mid-tract. Mucous gland cells are also frequent on the frontal surfaces of both inner and outer filaments.

The cilia of the filaments are arranged in four tracts; frontal, abfrontal and paired lateral. The dexioplectic wave of the laterals is obvious.

The ciliary feeding mechanism is essentially similar to that already described in Macandrevia cranium (Müller) by Atkins (1956), except for some slight differences in the direction of the mantle currents due to the greater width of the valves. It is intended to write a comprehensive account of feeding in brachiopods with plectolophous lophophores, when these differences will be noted.

\section{MEGERLIA ECHINATA (FISCHER \& OEHLERT)}

A number of Megerlia echinata (Fischer \& Oehlert) of shell length $\mathrm{I} \cdot 2 \mathrm{~mm}$ and width $\mathrm{I} .3 \mathrm{~mm}$ to shell length $13.5 \mathrm{~mm}$ and width $18.5 \mathrm{~mm}$ were dredged by R.V. 'Sarsia' in May $195^{\circ}$ in positions $47^{\circ} 25^{\prime}$ N., $6^{\circ} 30^{\prime}$ W., at a depth of $320-490$ fathoms; and $47^{\circ} 57^{\prime}$ N., $7^{\circ} 54^{\prime}$ W., at a depth of $390-350$ fathoms. In the first position they were attached in fair numbers to the dead part of probably growing coral, Lophelia prolifera (L.), in company with Platidia anomioides (Philippi), Megathyris detruncata (Gmelin) and Crania anomala (Müller); the latter were mostly cream coloured. In the second position five Megerlia echinata were taken, three on coral and two on a large oyster-like valve; one of those on the shell was the largest seen, being $13.5 \mathrm{~mm}$ long and $18.5 \mathrm{~mm}$ wide. During its first 2 days in the laboratory it gaped naturally some 5 or $6 \mathrm{~mm}$ in front; the filaments, however, did not extend. After the second day it remained closed, but at intervals lifted itself some $3 \mathrm{~mm}$ in front from the shell to which it was attached. It was dead in a few days. This specimen is considerably larger than the maximum size of length $9 \mathrm{~mm}$ and width $\mathrm{I} 2 \mathrm{~mm}$ recorded by Fischer \& Oehlert (I89I) and I2 $\mathrm{mm}$ by $16 \mathrm{~mm}$ recorded by Massey (1925).

In July 1959 in position $47^{\circ} 37^{\prime}$ N., $7^{\circ} 28^{\prime}$ W., at a depth of 780 fathoms three M. echinata were dredged attached to an oyster-like valve.

Altogether some I20 M. echinata have been dredged. Those on the oysterlike valves were regularly transverse oval, while those on Lophelia were frequently irregular in shape owing to crowding by the coral polyps. Some occupied the empty coral cups (Atkins, 1961 a). Unlike M. echinata, Platidia anomioides (Philippi) growing on the same coral and with the same habit, 
were generally regular in shape (Atkins, I959a); this was no doubt because of their small size, with maximum length $4.6 \mathrm{~mm}$.

Carmine pigment spots present in $M$. truncata are absent in the deep water M. echinata.

A single $M$. echinata of those dredged in May 1958 survived in the tanks to June 1960. A number were alive in September 1959, but most were dead by December I959. M. echinata proved less difficult to relax than M. truncata.

\section{Growth stages of the lophophore and loop}

A fuller series of growth stages of the lophophore and loop were obtained in M. echinata than in M. truncata.

At a shell length of $\mathrm{I} \cdot 4 \mathrm{~mm}$ and width of $\mathrm{I} \cdot 3 \mathrm{~mm}$ the late trocholophous lophophore has I6 pairs of long filaments in single series. Both crura and septum are absent. At the same length but with a width of $\mathrm{I} .6 \mathrm{~mm}$ the circle of the lophophore is slightly interrupted in the anterior mid-line; a septum is still absent. A few more filaments are present than in the preceding stage,

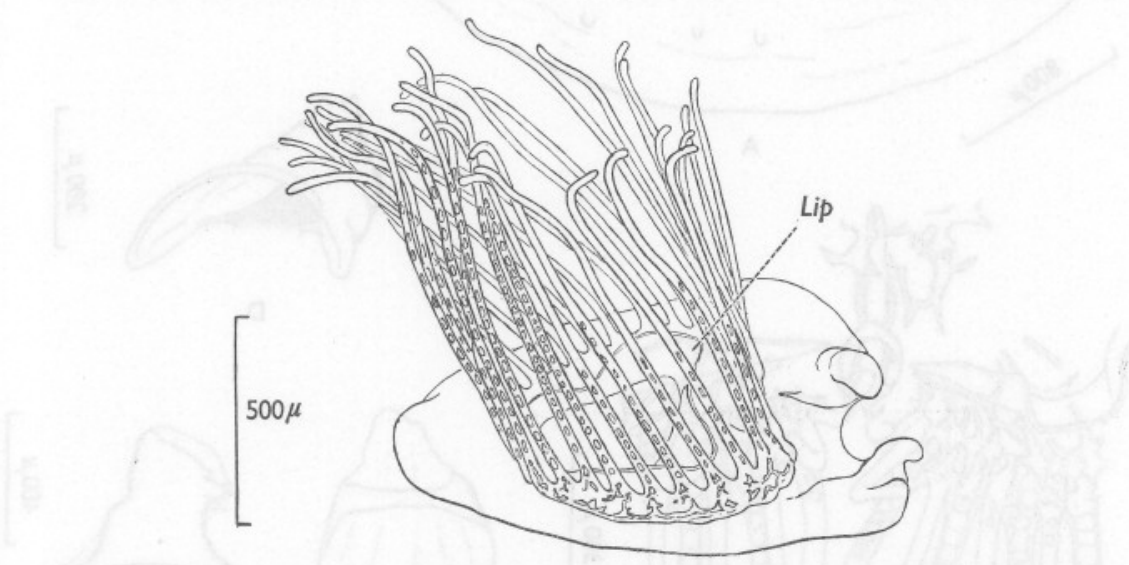

Fig. Io. Megerlia echinata of shell length $\mathrm{I} \cdot 4 \mathrm{~mm}$ and width $\mathrm{I} \cdot 6 \mathrm{~mm}$. Side view of brachial valve with very early schizolophe, narcotized and fixed in formalin. Spicules indicated except in the filaments of the far side. Lip, lip of the food groove.

and two outer grooved filaments have appeared on each side. As in the smaller specimen spicules occur at the base of the lophophore, except at the growth region. They are also present in the filaments, extending much farther along the anterior than the posterior ones. The filaments are considerably longer than in the same stage of $M$. truncata; their length may be judged from Fig. IO. In this specimen a small crus is present on one side: tubercles are lacking on the inner surface of the valves.

At a shell length of $2.15 \mathrm{~mm}$ and width of $2.4 \mathrm{~mm}$ the lophophore is very early schizolophous. A septum has not yet appeared; crural bases only are distinguishable. A few tubercles occur on the inner surface of the valves. 
When a shell length of $2.6 \mathrm{~mm}$ and width of $2 \cdot 7-3.2 \mathrm{~mm}$ has been attained the lophophore is early schizolophous with a low septum, on the anterior end of which is a hood (Fig. II C). At the same length, but with a width of $3.6 \mathrm{~mm}$, short crura are present and the hood is wider (Fig. II A, B). In different individuals the septum varies in shape and length, as does also the hood (Fig. II A-D).

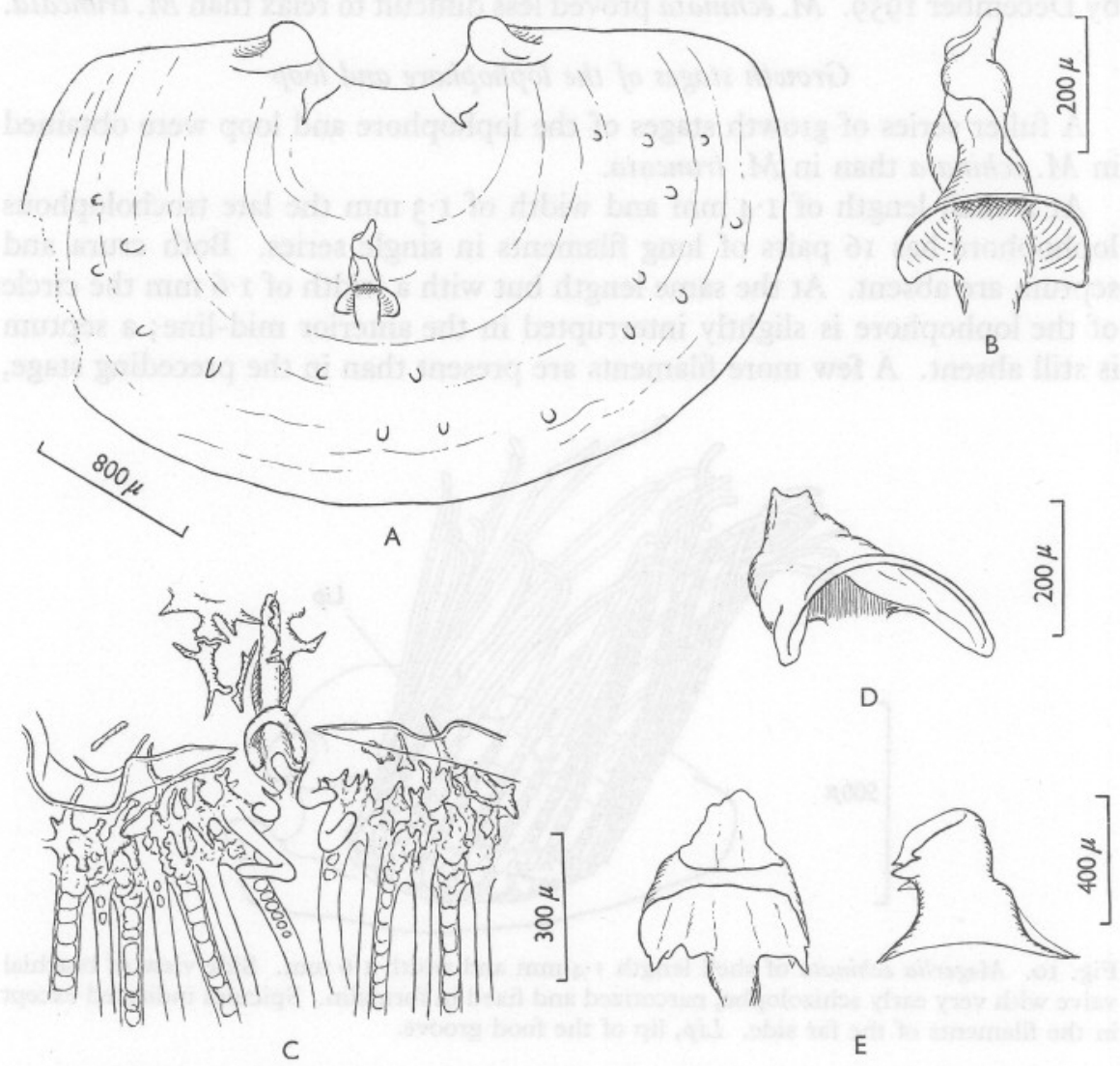

Fig. II. Megerlia echinata. A. Ventral view of brachial valve of an individual of shell length $2.6 \mathrm{~mm}$ and width $3.6 \mathrm{~mm}$. B, Septum and hood enlarged. C. Anterior region of early schizolophe of individual of shell length $2.6 \mathrm{~mm}$ and width $3.2 \mathrm{~mm}$. D. Septum and hood of individual of length $3.1 \mathrm{~mm}$ and width $3.0 \mathrm{~mm}$. E. Septum and hood in ventral and side view of a specimen of length $3.6 \mathrm{~mm}$ and width $4.7 \mathrm{~mm}$.

The lophophore is schizolophous at a shell length of $2.9 \mathrm{~mm}$ and width of $3.7 \mathrm{~mm}$. The posterior end of the hood has undergone resorption and there is now a transverse band, while the anterior edges of the hood bear spines. The septum and hood of the same lophophore stage are illustrated from a specimen of shell length $3.6 \mathrm{~mm}$ and width $4.7 \mathrm{~mm}$ (Fig. II E). 
The lophophore is late schizolophous at a shell length of $4 \cdot 2 \mathrm{~mm}$ and width of $5.2 \mathrm{~mm}$. The brachial support is about as advanced as that shown in Fig. I3 of a specimen of shell length $6.2 \mathrm{~mm}$ and width $7.4 \mathrm{~mm}$. Descending branches are beginning to grow from the crura. In an irregularly shaped specimen of shell length $6.0 \mathrm{~mm}$ and width $6.9 \mathrm{~mm}$, with a somewht more advanced lophophore, the lateral arms being deflected, the loop is in the stage depicted of a specimen of length $4.5 \mathrm{~mm}$ and width $8.0 \mathrm{~mm}$ (Fig. I2), but the crura are less developed.

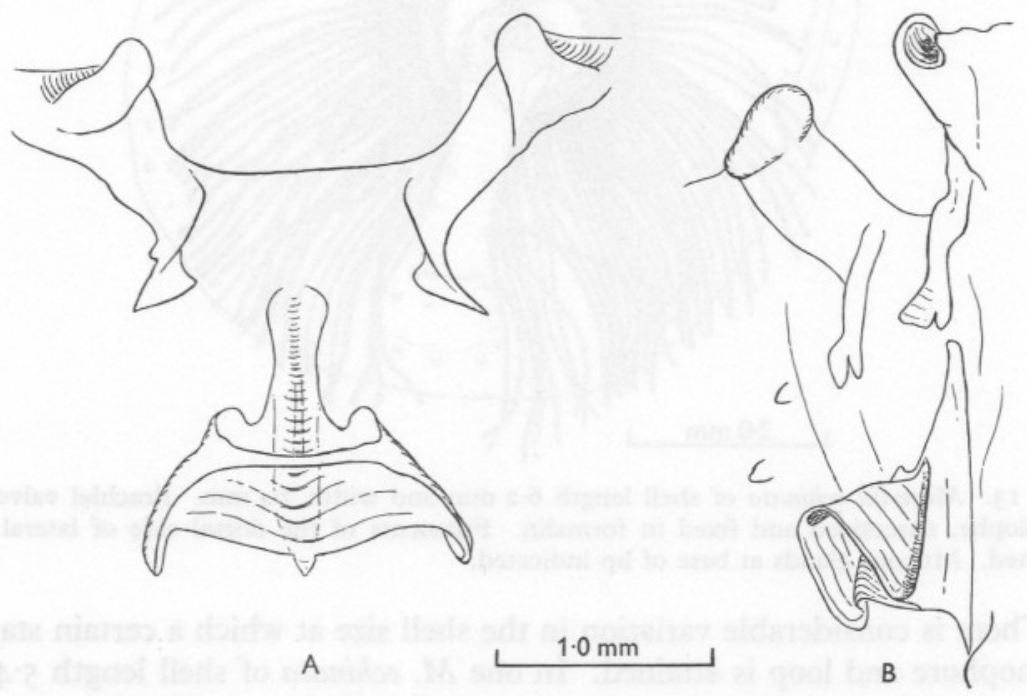

Fig. 12. Megerlia echinata of shell length $4.5 \mathrm{~mm}$ and width $8.0 \mathrm{~mm}$. Brachidium in (A) ventral and (B) side view.

In another irregularly shaped M. echinata of shell length 6.I $\mathrm{mm}$ and width $7 \cdot 2 \mathrm{~mm}$ the lophophore is early zygolophous, with the side arms still only slightly deflected. The anterior extensions of the ring have come to point outwards and backwards. The position of the transverse band to the growth zones of the lophophore is similar to that shown in Fig. 5 of $M$. truncata at a shell length of $4.3 \mathrm{~mm}$ and width of $5.6 \mathrm{~mm}$.

The zygolophous stage with side arms deflected is found in a specimen of shell length $6.2 \mathrm{~mm}$ and width $7.4 \mathrm{~mm}$ (Fig. I3). The brachial support is surprisingly retarded in development for the stage of lophophore.

It will be seen from the foregoing that there is sometimes little change in the brachial support between the late schizolophe with lateral arms only slightly deflected to the zygolophe with lateral arms entirely deflected, but in some individuals at the later stage of lophophore development the support may be as advanced as in that of the early plectolophe. In the specimen of shell length $4.5 \mathrm{~mm}$ and width $8.0 \mathrm{~mm}$ (Fig. I2) the transverse band is some- 
what wider from left to right than in that of shell length $6 \cdot 2 \mathrm{~mm}$ and width $7.4 \mathrm{~mm}$ (Fig. 13), and the two divergent processes project well forward. In both, crural processes are present and the beginnings of the descending branches.

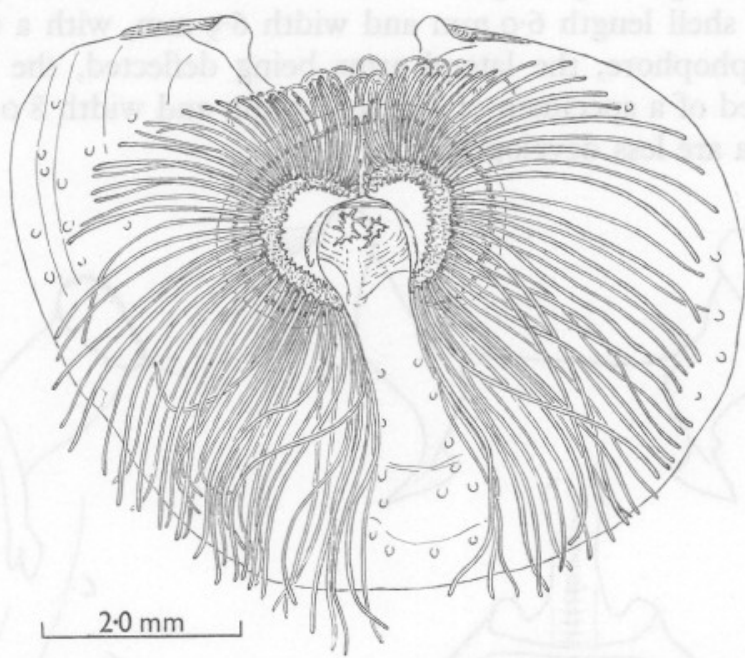

Fig. 13. Megerlia echinata of shell length $6 \cdot 2 \mathrm{~mm}$ and width $7 \cdot 4 \mathrm{~mm}$. Brachial valve with zygolophe, narcotized and fixed in formalin. Filaments of the dorsal side of lateral arms omitted. Mucous glands at base of lip indicated.

There is considerable variation in the shell size at which a certain stage of lophophore and loop is attained. In one $M$. echinata of shell length $5.4 \mathrm{~mm}$ and width $6.6 \mathrm{~mm}$ the lophophore is early plectolophous with one turn to the spiral arm. This seems to be an unusually small shell size for this stage of lophophore. The loop is as in the specimen of shell length $6.2 \mathrm{~mm}$ and width $8.7 \mathrm{~mm}$ illustrated in Fig. I4. The posterior portions of the descending branches have begun to grow from the crura, while the anterior portions have begun to grow backwards from the antero-lateral divergent processes, which apparently represent the anterior portions of both ascending and descending branches (see Elliott, I949, p. 542, on Kraussina).

The lophophore can be fully plectolophous from a shell length of $9 \mathrm{~mm}$ and width of II mm (Fig. 15). The filaments are in an inner and outer alternating series, except for some sixteen pairs behind the mouth, which are in single series and have ridged frontal surfaces. The adult loop of a specimen of shell length $12.0 \mathrm{~mm}$ and width $15.6 \mathrm{~mm}$ is shown in Fig. I6. The descending branches are complete. On one side lacunae have been formed by resorption between the descending and ascending portions of the loop. The median septum now extends as a low ridge almost to the cardinal margin. The outer filaments are heavily spiculated, the inner slightly. At the base of the filaments the granulated and the clear spicules are crowded (Fig. 9B). 

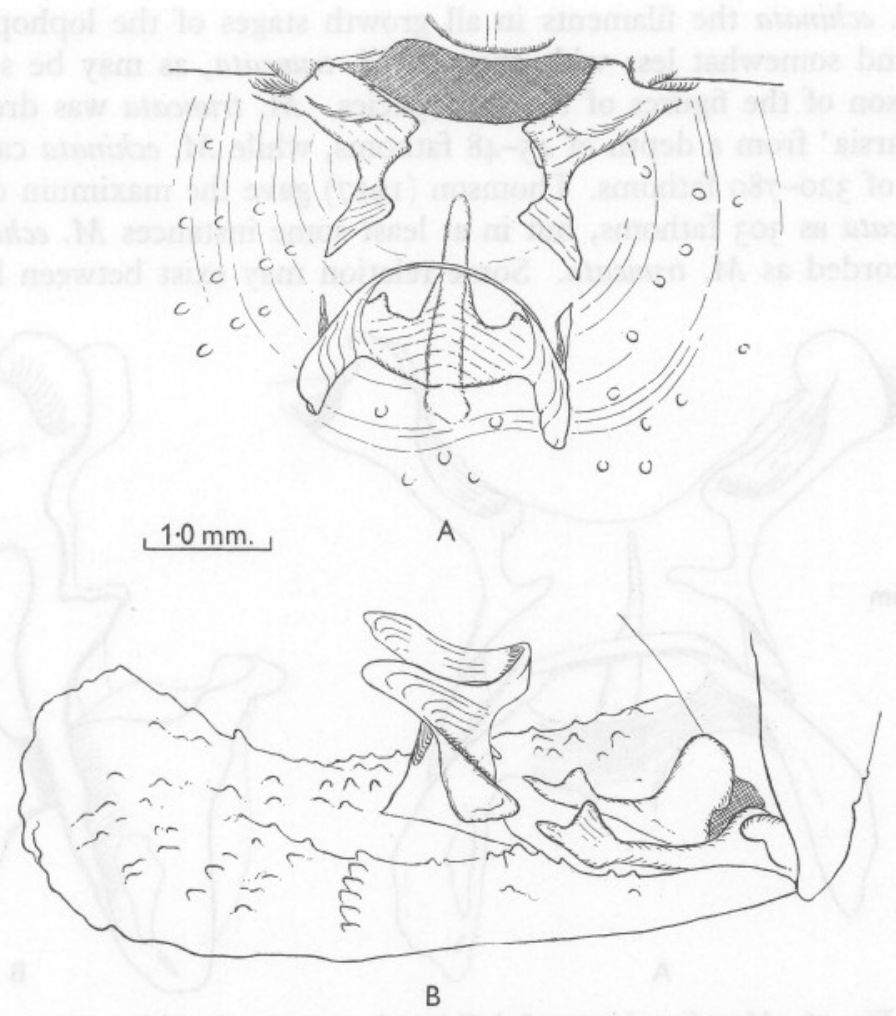

Fig. 14. Megerlia echinata of shell length $6 \cdot 2 \mathrm{~mm}$ and width $8 \cdot 7 \mathrm{~mm}$. Brachidium in (A) ventral and (B) side view.,

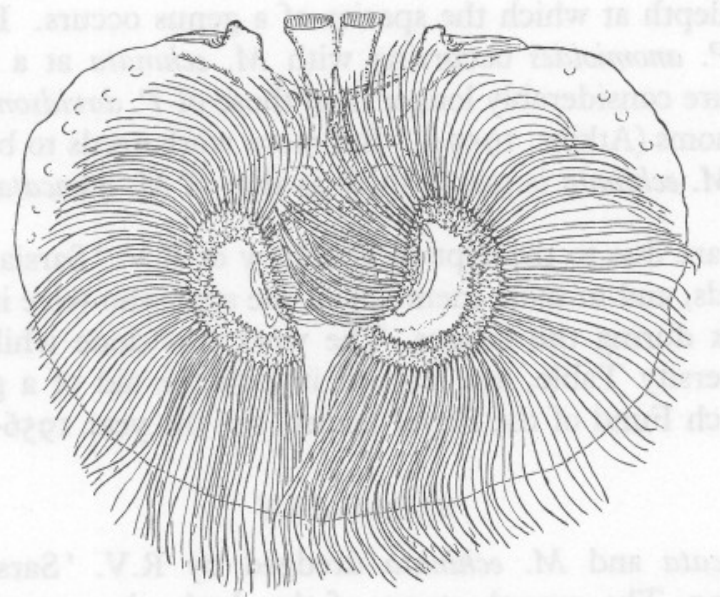

Fig. 15. Megerlia echinata of shell length $9 \mathrm{~mm}$ and width II $\mathrm{mm}$. Brachial valve with plectolophe. 
In $M$. echinata the filaments in all growth stages of the lophophore are longer and somewhat less wide than in M. truncata, as may be seen by a comparison of the figures of the two species. M. truncata was dredged by R.V. 'Sarsia' from a depth of $45-48$ fathoms, while M. echinata came from a depth of 320-780 fathoms. Thomson (1927) gave the maximum depth for M. truncata as 303 fathoms, but in at least some instances M. echinata has been recorded as $M$. truncata. Some relation may exist between length of

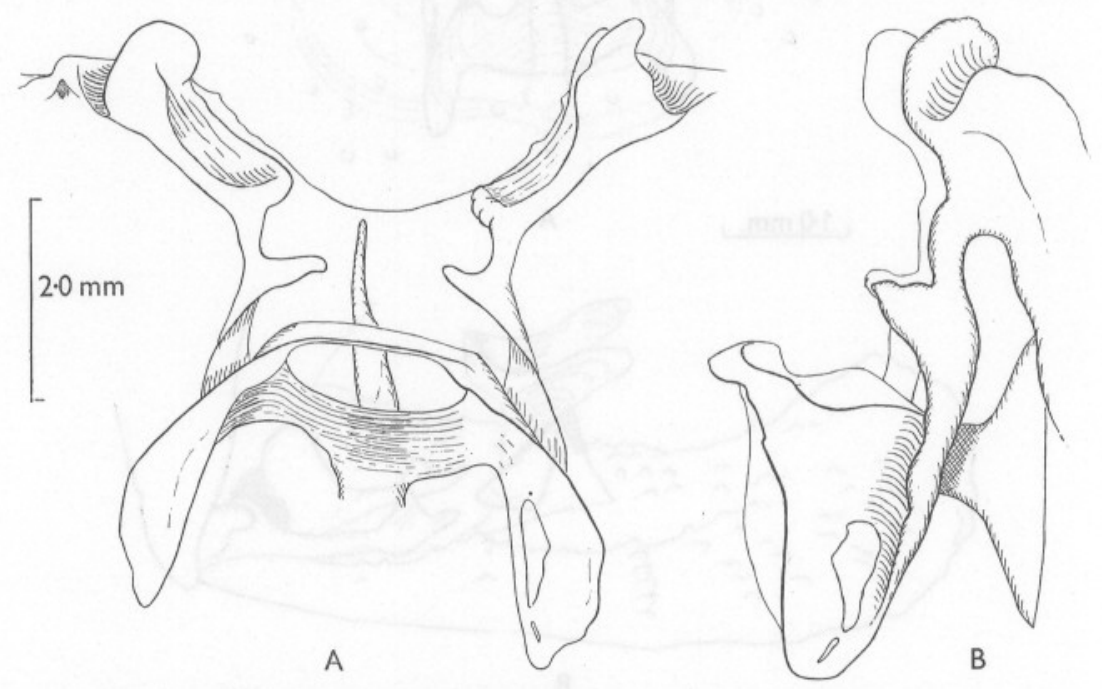

Fig. 16. Megerlia echinata of shell length $12 \mathrm{~mm}$ and width $15.6 \mathrm{~mm}$. Adult brachidium (A) ventral and (B) side view.

filament and depth at which the species of a genus occurs. In Platidia, the filaments of $P$. anomioides occurring with $M$. echinata at a depth of $320-$ 780 fathoms, are considerably longer than those of $P$. davidsoni from a depth of 45-220 fathoms (Atkins, I959a). But more work needs to be done on this. The shell of M. echinata is not as thick as that of M. truncata.

My thanks are due to the captain and crew of R.V. 'Sarsia' who dredged the brachiopods, and to those members of the staff who were in charge of the scientific work during the cruises. The work was done while occupying a London University Table, and part of it with the aid of a grant from the Brown Research Fund of the Royal Society for the year 1956-57.

\section{SUMMARY}

Megerlia truncata and M. echinata dredged by R.V. 'Sarsia' have been examined living. The growth stages of the lophophore are described and figured, the series being fuller in M. echinata than in M. truncata. The 
adult lophophore of $M$. truncata has been sectioned and its structure described.

The ciliary feeding mechanism in Megerlia is similar to that already described by the author in brachiopods with plectolophous lophophores.

\section{REFERENCES}

Atkins, D., 1956. Ciliary feeding mechanisms of brachiopods. Nature, Lond., Vol. 177, pp. 706-7.

- $1959 \mathrm{a}$. The growth stages of the lophophore of the brachiopods Platidia davidsoni (Eudes Deslongchamps) and $P$. anomioides (Philippi), with notes on the feeding mechanism. F. mar. biol. Ass. U.K., Vol. 38, pp. 103-32.

- $1959 \mathrm{~b}$. The early growth stages and adult structure of the lophophore of Macandrevia cranium (Müller) (Brachiopoda, Dallinidae). F. mar. biol. Ass. U.K., Vol. 38, pp. 335-50.

- $1959 \mathrm{c}$. The growth stages of the lophophore and loop of the brachiopod Terebratalia transversa (Sowerby). F. Morph., Vol. 105, pp. 40I-26.

- 196r $a$. The generic position of the brachiopod Megerlia echinata (Fischer \& Oehlert). F. mar. biol. Ass. U.K., Vol. 4I, pp. 89-94.

- I96r $b$. A note on the growth-stages and structure of the adult lophophore of the brachiopod Terebratella (Waltonia) inconspicua (G. B. Sowerby). Proc. zool. Soc. Lond., Vol. 136, pp. 255-71.

Davidson, T., 1887. A monograph of recent Brachiopoda. Part II. Trans. Linn. Soc. Lond. (Zool.), Ser. 2, Vol. 4, pp. 75-182.

Elliotr, G. F., I949. The brachial development of Kraussina (Brachiopoda). Ann. Mag. nat. Hist., Ser. 12, Vol. 2, pp. 538-46.

EUdES DesLONGCHAMPS, E., I884. Notes sur les modifications à apporter à la classification des Terebratulidae. Bull. Soc. linn. Normandie, Sér. 3, Vol. 8, pp. I6I297.

Fischer, P. \& OeHLERT, D.-P., I89I. Brachiopodes. Expéd. sci. Travailleur et Talisman, $140 \mathrm{pp}$.

Jefrereys, J. G., I878. On the Mollusca procured during the 'Lightening' and 'Porcupine' Expeditions, 1868-70. (Part I.) Proc. zool. Soc. Lond., I878, pp. 393-416.

Massey, A. L., I925. The Brachiopoda of the coast of Ireland. Proc. Roy. Irish Acad. B, Vol. 37, pp. 37-46.

PhIlippi, R. A., I836. Enumeratio Molluscorum Siciliae, Vol. I.

Thомson, J. A., 1927. Brachiopod morphology and genera (Recent and Tertiary). N.Z. Bd Sci. Art, Manual 7.

Williams, A., I956. The calcareous shell of the Brachiopoda and its importance to their classification. Biol. Rev., Vol. 31, pp. 243-87. 